\title{
Effect of $\beta$-Glucans in Diets on Growth, Survival, Digestive Enzyme Activity, and Immune System and Intestinal Barrier Gene Expression for Tropical Gar (Atractosteus tropicus) Juveniles
}

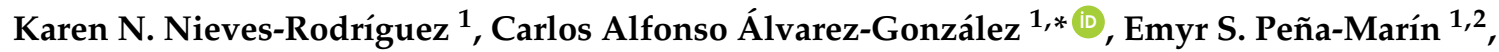 \\ Fernando Vega-Villasante ${ }^{3}$, Rafael Martínez-García ${ }^{1}$, Susana Camarillo-Coop ${ }^{1}$, \\ Dariel Tovar-Ramírez ${ }^{4}$, Laura T. Guzmán-Villanueva ${ }^{4,5}$, Karl B. Andree ${ }^{6}$ and Enric Gisbert ${ }^{6}$ \\ 1 Laboratorio de Acuicultura Tropical, División Académica de Ciencias Biológicas, Universidad Juárez \\ Autónoma de Tabasco, Km 0.5 Carretera Villahermosa-Cárdenas Entronque a Bosques de Saloya, \\ Centro 86039, Tabasco, Mexico; kammy526@hotmail.com (K.N.N.-R.); ocemyr@yahoo.com.mx (E.S.P.-M.); \\ biologomartinez@hotmail.com (R.M.-G.); susana.camarillo.coop@gmail.com (S.C.-C.) \\ 2 Cátedra Consejo Nacional de Ciencia y Tecnología, Universidad Juárez Autónoma de Tabasco, \\ Ciudad de Mexico 03940, Mexico \\ 3 Laboratorio de Calidad de Agua y Acuicultura Experimental, Centro de Investigaciones Costeras, \\ Universidad de Guadalajara, Puerto Vallarta, Jalisco 48280, Mexico; fernandovega.villasante@gmail.com \\ 4 Laboratorio de Fisiología Comparada y Genómica Funcional, Centro de Investigaciones Biológicas del \\ Noroeste, Calle IPN 195, La Paz BCS 23096, Mexico; dtovar04@cibnor.mx (D.T.-R.); \\ laurididae@hotmail.com (L.T.G.-V.) \\ 5 Cátedra Consejo Nacional de Ciencia y Tecnología, Centro de Investigaciones Biológicas del Noroeste, \\ Ciudad de Mexico 03940, Mexico \\ 6 Unitat de Cultius Aqüicoles, Institut de Recerca i Tecnologia Agroalimentàries (IRTA), Sant Carles de la \\ Ràpita, Tarragona 43540, Spain; karl.Andree@irta.es (K.B.A.); enric.gisbert@irta.cat (E.G.) \\ * Correspondence: alvarez_alfonso@hotmail.com; Tel.: +52-993-358-1500
}

Received: 5 June 2018; Accepted: 4 July 2018; Published: 10 July 2018

\begin{abstract}
The application of $\beta-1,3 / 1,6$-glucan derived from yeast at five concentrations $(0 \%, 0.5 \%$, $1.0 \%, 1.5 \%$, and $2.0 \%$ ) in formulated diets was evaluated in juveniles for its effects on the growth, survival, digestive enzymatic activity, and expression of genes associated with the immune system (interlukin-10 (IL-10), transforming growth factor (TGF), occludin (OCC), mucin2 (MUC2), lysozyme (LYS), and nucleotide-binding and oligomerization domain 2 (NOD2)) in tropical gar (Atractosteus tropicus). For the experiment, three replicates of 30 fish per experimental unit $(70 \mathrm{~L})$ were cultivated for 62 days. The growth results showed no statistically significant differences in relation to weight and total length between treatments. The activity of digestive enzymes (alkaline proteases, trypsin, leucine aminopeptidase, and amylase) did not show significant differences between treatments, except for chymotrypsin activity, where fish fed $1.0 \%$ and $1.5 \%$ of $\beta$-glucans showed higher activities compared with the rest of the treatments. On the other hand, the analysis of gene expression did not show significant differences between treatments, although a tendency of increase in the expression of IL-10, TGF, MUC2, and OCC was observed with an addition of $1.5 \%$ of the prebiotic, but there was a decrease in the fish fed with $2 \%$ of the prebiotic. It is possible to include concentrations of between $0.5 \%$ and $1.5 \%$ of $\beta$-glucans in the diets for $A$. tropicus, with no detectable adverse effects on growth, survival, digestive enzyme activity, or specific gene expression. $\beta$-glucan $1,3 / 1,6$ added at $1.0 \%$ and $1.5 \%$ in the diet significantly increases chymotrypsin activity.
\end{abstract}

Keywords: aquaculture; immune system; nutrition; prebiotics; $A$. tropicus 


\section{Introduction}

Aquaculture in the southeast of Mexico has great potential, especially with the use of native freshwater species, significant among which is the tropical gar, or so-called pejelagarto (Atractosteus tropicus, Gill 1863). However, the production of this species has been limited by the lack of studies regarding the development of specific foods that allow maximizing their growth and survival and increasing production on a commercial scale [1]. For this reason, several studies on A. tropicus have focused on maximizing the production performance of the species [2], developing balanced foods based on digestive physiology [3], and improving the growth and utilization of nutrients [4,5]. On the other hand, health impacts due to outbreaks of diseases under culture conditions generate large economic losses [6]; therefore, to reduce this impact, the use of immunostimulants could enhance the immune response and increase resistance of the organism against infectious diseases [7]. In this regard, $\beta$-glucans are one of the prebiotics with greater interest in the area of aquaculture. Specifically, the $\beta-1,3 / 1,6$-glucan from the cell walls of yeast (Saccharomyces cerevisiae, Hansen 1883) is one the most studied prebiotics, and is composed of a heterogeneous group of glucose polymers consisting of a backbone of $\beta-1,3$-linked $\beta$-D-glucopyranosyl units with $\beta-1,6$-linked side chains of varying distribution and length. Such chemical structures are abundant in microbial communities and can be termed pathogen-associated molecular patterns (PAMP), which play a role as alarm molecules to activate the immune system [8] via their binding to pattern recognition receptors (PRRs), such as Toll-like receptors (TLRs), scavenger receptors (SR), and dectin-1, which allow the activation of the inflammatory response and the synthesis of cytokines [8-10]. These receptors activate leukocytes directly to stimulate phagocytosis, cytotoxic and antimicrobial activity, and also to modulate the production of cytokines that control networks responsible for innate immune responses [11], promote growth [12,13], improve survival [14,15], stimulate antibody production [16], and modulate expression of genes related to various immune system pathways [17].

Studies conducted on different fish species, such as Atlantic salmon (Salmo salar, Linnaeus 1758) [18], rainbow trout (Oncorhynchus mykiss, Walbaum 1792) $[15,19,20]$, spotted rose snapper (Lutjanus guttatus, Steindachner 1869) [21], common carp (Cyprinus carpio, Linnaeus 1758) [16,22,23], roho labeo (Labeo rohita, Hamilton 1822) [13,24], gilthead sea bream (Sparus aurata Linnaeus 1758) [25], sea bass (Dicentrarchus labrax, Linnaeus 1758) [26,27], Nile tilapia (Oreochromis niloticus, Linnaeus 1758) [28], silver seabream (Pagrus auratus, Forster 1801) [12], large yellow croaker (Pseudosciaena crocea, Richardson 184) [29], and southern bluefin tuna (Thunnus maccoyii, Castelnau 1872) [30] have reported that $\beta$-glucans act by modulating different parameters of the immune response and increasing resistance to diseases $[8,12]$. Therefore, the objective of the present study was to determine the effect of different oral doses of $\beta-1,3 / 1,6$-glucan on growth, survival, digestive enzymatic activity, and the expression of several genes associated with the immune system and the intestinal barrier function in juveniles of the tropical gar (A. tropicus).

\section{Results}

The tropical gar were fed diets supplemented with $\beta-1,3 / 1,6$-glucans at different concentrations $(0 \%, 0.5 \%, 1.0 \%, 1.5 \%$ and $2.0 \%)$ for 62 days. No significant differences were observed in survival or growth variables, such as final weight, total length, specific growth rate (SGR), feed conversion ratio (FCR) and condition factor (K) values (Table 1 ). 
Table 1. Survival and growth parameters of $A$. tropicus fed formulated diets with different concentrations of $\beta-1,3 / 1,6$ glucans $(0 \%, 0.5 \%, 1.0 \%, 1.5 \%$, and $2.0 \%)$.

\begin{tabular}{|c|c|c|c|c|c|c|}
\hline \multicolumn{7}{|c|}{ Treatments ( $\beta-1,3 / 1,6$ Glucans $)$} \\
\hline \multicolumn{2}{|c|}{ Growth Parameters } & \multirow{3}{*}{$\begin{array}{c}\mathbf{0 \%} \\
4.60 \pm 0.11 \\
12.10 \pm 0.19\end{array}$} & \multirow{3}{*}{$\begin{array}{c}\mathbf{0 . 5 \%} \\
4.64 \pm 0.06 \\
12.13 \pm 0.17\end{array}$} & \multirow{3}{*}{$\begin{array}{c}\mathbf{1 . 0 \%} \\
4.62 \pm 0.09 \\
12.35 \pm 0.73\end{array}$} & \multirow{3}{*}{$\begin{array}{c}\mathbf{1 . 5 \%} \\
4.64 \pm 0.09 \\
12.52 \pm 0.87\end{array}$} & \multirow{3}{*}{$\begin{array}{c}\mathbf{2 . 0 \%} \\
4.65 \pm 0.06 \\
12.27 \pm 0.29\end{array}$} \\
\hline Total lenoth (mm) & Initial & & & & & \\
\hline lotal length (mm) & Final & & & & & \\
\hline \multirow{2}{*}{ Weight (g) } & Initial & $0.47 \pm 0.03$ & $0.46 \pm 0.06$ & $0.44 \pm 0.07$ & $0.52 \pm 0.03$ & $0.52 \pm 0.09$ \\
\hline & Final & $5.64 \pm 0.49$ & $5.40 \pm 0.17$ & $5.91 \pm 1.11$ & $6.14 \pm 1.49$ & $5.76 \pm 0.29$ \\
\hline \multirow{4}{*}{\multicolumn{2}{|c|}{$\begin{array}{c}\text { Survival }(\%)^{1} \\
\text { SGR }\left(\% \text { day }^{-1}\right)^{2} \\
\text { FCR }^{3} \\
\mathrm{~K}^{4}\end{array}$}} & $96.9 \pm 2.69$ & $93.1 \pm 1.53$ & $95.3 \pm 3.52$ & $91.3 \pm 2.90$ & $95.6 \pm 5.09$ \\
\hline & & $4.75 \pm 0.29$ & $4.74 \pm 0.28$ & $4.99 \pm 0.09$ & $4.69 \pm 0.33$ & $4.79 \pm 0.02$ \\
\hline & & $0.31 \pm 0.02$ & $0.30 \pm 0.01$ & $0.30 \pm 0.01$ & $0.31 \pm 0.01$ & $0.30 \pm 0.01$ \\
\hline & & $326.4 \pm 27.0$ & $302.6 \pm 32.3$ & $313.8 \pm 30.4$ & $312.9 \pm 26.9$ & $311.8 \pm 10.9$ \\
\hline
\end{tabular}

${ }^{1}$ Survival (\%): (final fish number/initial fish number) $\times 100 ;{ }^{2}$ Specific growth rate (SGR): [(ln final weight-ln initial weight)/days] $\times 100 ;{ }^{3}$ Feed conversion ratio (FCR): (feed intake, g dry matter)/(fish weight gain, g); ${ }^{4}$ Condition factor $(\mathrm{K})$ : (final mean body weight/ final mean body length $\left.{ }^{3}\right) \times 100$.

The results of the enzymatic digestive activities showed a significant increase $(p<0.05)$ for chymotrypsin activity in fish fed with glucans at $1.0 \%$ and $1.5 \%(8.97 \pm 2.40$ and $8.30 \pm 1.02 \mathrm{U} \mathrm{mg}$ protein $^{-1}$, respectively) as compared to the other diets. However, total alkaline proteases, trypsin, leucine aminopeptidase, lipase, and $\alpha$-amylase did not show significant differences between the different treatments (Table 2).

Table 2. Digestive enzymatic activity in A. tropicus fed formulated diets supplemented with $\beta-1,3 / 1,6$ glucans at different concentrations $(0 \%, 0.5 \%, 1.0 \%, 1.5 \%$, and $2.0 \%)$.

\begin{tabular}{cccccc}
\hline \multicolumn{5}{c}{ Treatments ( $\mathbf{\beta - 1 , 3 / 1 , 6}$ Glucans) } \\
\hline $\begin{array}{c}\text { Enzymatic Activity } \\
\text { (U mg Protein }\end{array}{ }^{-1}$ ) & $\mathbf{0 \%}$ & $\mathbf{0 . 5 \%}$ & $\mathbf{1 . 0} \%$ & $\mathbf{1 . 5 \%}$ & $\mathbf{2 . 0 \%}$ \\
\hline Total alkaline proteases & $1.26 \pm 0.43$ & $1.34 \pm 0.23$ & $0.86 \pm 0.23$ & $1.03 \pm 0.23$ & $0.71 \pm 0.42$ \\
Trypsin & $4.06 \pm 0.32$ & $3.76 \pm 2.99$ & $1.78 \pm 1.13$ & $2.90 \pm 1.54$ & $2.80 \pm 1.05$ \\
Leucine peptidase & $5.86 \pm 3.47$ & $8.38 \pm 2.75$ & $7.18 \pm 3.08$ & $5.56 \pm 2.19$ & $5.14 \pm 1.63$ \\
Chymotrypsin * & $1.14 \pm 0.74^{\mathrm{b}}$ & $1.12 \pm 0.65^{\mathrm{b}}$ & $8.97 \pm 2.40^{\mathrm{a}}$ & $8.03 \pm 1.02^{\mathrm{a}}$ & $1.21 \pm 1.04^{\mathrm{b}}$ \\
Lipase & $2.52 \pm 0.15$ & $2.83 \pm 0.08$ & $2.78 \pm 0.34$ & $2.84 \pm 0.25$ & $2.50 \pm 0.16$ \\
$\alpha$-amylase & $0.66 \pm 0.17$ & $3.90 \pm 2.36$ & $6.78 \pm 3.30$ & $9.00 \pm 5.44$ & $7.80 \pm 1.03$ \\
\hline * The superscripts a and b show the statistically significant differences between treatments $(p<0.05)$.
\end{tabular}

${ }^{*}$ The superscripts a and $\mathrm{b}$ show the statistically significant differences between treatments $(p<0.05)$.

Regarding gene expression results, data analysis revealed that there were no statistically significant differences among groups $(p>0.05)$, which was mainly attributed to a high inter-individual variability. However, a trend was observed in the data related to the increase of dietary $\beta$-glucans. This trend is summarized as follows: in the case of interlukin-10 ( $I L-10)$, it was noted that the treatment of $\beta$-glucans at $2.0 \%$ was greater compared to the other treatments with lower concentrations of $\beta$-glucans. The expression of transforming growth factor (TGF) in the treatment with $0.5 \%$ of $\beta$-glucans was lower compared to the treatments with higher prebiotic inclusion. While the expression of occludin (OCC) showed a higher value in the fish fed with the lowest concentration $(0.5 \%)$, decreasing expression was found in the treatments with greater amount of the prebiotic. Considering mucin2 (MUC2) expression, there was a clear tendency to increase its expression as the concentration of $\beta$-glucans increased up to $1.5 \%$; nevertheless, higher concentration of $\beta$-glucans $(2.0 \%)$ decreased the relative expression considerably (Figure 1). 

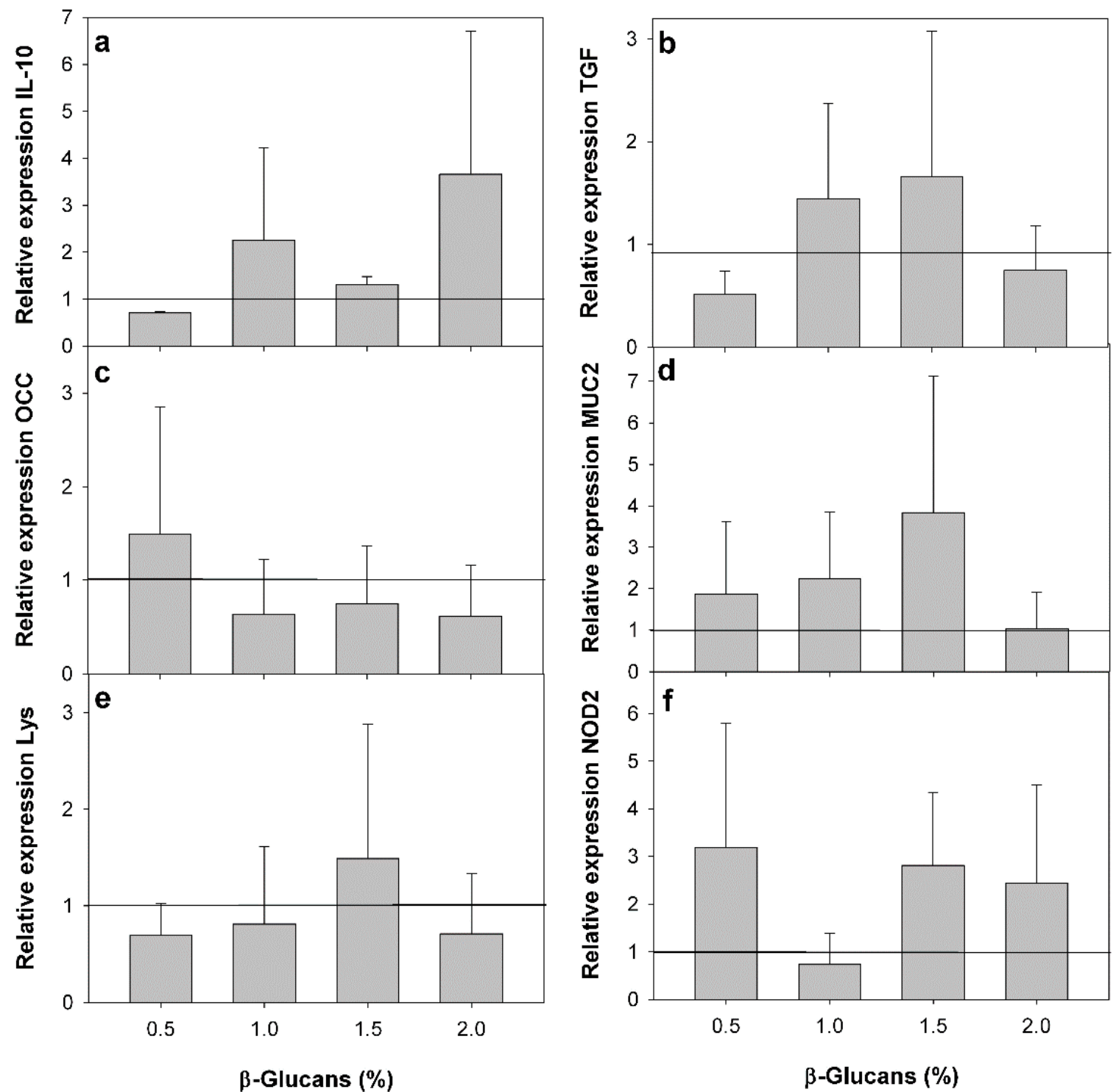

Figure 1. Box-plot of the relative expression different molecular markers from the intestinal tissue (median \pm quartile $10 \%, n=3$ ) of A. tropicus juveniles normalized to the average of Elongation factor 1 (EF1) and $\beta$-actin expression. (a) Interlukin-10 (IL-10); (b) transforming growth factor (TGF); (c) Occludin (OCC); (d) Mucin2 (MUC2); (e) Lysozyme (Lys); (f) nucleotide-binding and oligomerization domain 2 (NOD2) (K-W, $p>0.05)$.

\section{Discussion}

Within fish culture systems of the aquaculture industry there are sources of stress (crowding, handling, transport) that put animals at higher risk of infectious disease as a consequence of the negative effects of increased cortisol levels resulting from the stressful conditions [16]. The ensuing diseases generate great economic losses during culture; therefore, the use of immunostimulants has increased in the aquaculture industry [21], with the prebiotic $\beta-1,3 / 1,6$-glucan being one of the most frequently used [31]. Under present experimental conditions, the incorporation of this prebiotic in balanced feeds designed for $A$. tropicus did not result in an improvement of the somatic growth parameters (body weight, length, SGR, FCR, and K). Many studies indicate that $\beta$-glucans promote the growth of aquatic animals in relation to the amount included in the feed, the duration of feeding, culture temperature, type of $\beta$-glucans, and species being raised [32]. However, the exact mechanism 
of how $\beta$-glucans promote growth in aquatic animals is not clear. Some authors suggest that somatic growth is enhanced due to the production of glucanase that decomposes $\beta$-glucans to generate energy [33,34], while others by the improvement of the intestinal immune response and indirectly promoting growth [8]. Nevertheless, it is known that this type of prebiotic does not necessarily promote an increase in somatic growth, which is consistent with the results obtained in several studies in turbot (Scophthalmus maximus, Linnaeus 1758) [35], O. mykiss [36], and cod (Gadus morhua, Linnaeus 1758) [37], where no differences were reported in the growth parameters, but there were differences in parameters related to the improvement of the immune system (see review in Reference [38]). In addition, under current experimental conditions, the incorporation of the prebiotic did not increase the survival among any of the treatments when compared to the control without the compound, but it must be mentioned that the survival was very high $(>90 \%)$, which agrees with results reported for Persian sturgeon (Acipenser persicus, Borodin 1897) [39] and O. niloticus [40].

Regarding the activity of digestive enzymes of the tropical gar fed with $\beta$-glucans, there was a decrease in chymotrypsin-like activity that correlated inversely with the concentration of $\beta$-glucan in the diet, whereas no differences in activity were found for the other assayed digestive enzymes. These results differed from data for the Pacific red snapper (Lutjanus peru, Nichols and Murphy 1922) [10], where the increase of $\beta$-glucans resulted in an increase in the activity of aminopeptidase, trypsin, and chymotrypsin, using concentrations between $0.1 \%$ and $0.2 \%$. These differences between current data and those obtained in L. peru might be explained by differences in the doses of $\beta$-glucans tested in both species. In the former study, doses were lower in comparison to those used in this work; there are also differences in the digestive physiology between marine species and freshwater tropical fish. Therefore, it may be possible that the high amounts of $\beta$-glucans used in the present study $(2.0 \%)$ could have contributed to a saturation of amino acid transporters that could promote a possible inhibition or inactivation of the digestive enzymes, as well as the possible alteration of the gut microbiota; however, there are few studies that evaluate what effects an excess of $\beta$-glucans has on the digestive capacity of fish [41]. The different effect $\beta$-glucans have on alkaline proteases, trypsin, and chymotrypsin ratio deserves further attention, as well as the potential role of this prebiotic on enhancing the digestive function in fish [42].

It is well known that $\beta$-glucans directly activate leukocytes, stimulate phagocytosis, cytotoxic, and antimicrobial activity, in addition to modulating the production of cytokines, which are responsible for controlling immune responses [11]. In relation to the cytokines evaluated in this work, TGF binds to its cognate receptor as part of inflammatory responses triggering a cascade of transcription that leads to cell differentiation, chemotaxis, proliferation, and activation of many immune cells [43] and IL-10 is responsible for decreasing and regulating the inflammatory responses produced by cells, as well as reducing the adaptive responses of T cells [44]. Studies in fry [45] and juveniles of O. mykiss [46] have reported $\beta$-glucans increase cytokine levels and mRNA expression of the $I L-10$ transcription factor, TGF- $\beta$, which was not in agreement with the results obtained in the present work. This may be due to the high interindividual variability and the administered concentration of glucans in the diet. Different studies show that concentrations higher than $0.5 \%$ of $\beta$-glucans have no effect on gene expression in different fish species [8]. Further, the effect of this immunostimulant is species-dependent and effects can vary with the route of administration (oral versus intraperitoneal injection).

The use of $\beta$-glucans has also been shown to improve physical barriers of the intestine, which are the first lines of immune defense of the host [47]. The mucus layer coating the intestinal mucosa is formed mainly by mucins, high molecular weight glycoproteins that help to form the composition of the mucus, determine its adhesiveness, viscoelasticity, transport, and protective capacity [48]. Herein, it was reported that the expression of MUC2 increased directly with the increase of $\beta$-glucans in the diet, which might suggest that the ability to regulate the expression of mucin is a benefit for responding to pathogens. However, a decrease in expression was observed in A. tropicus fed $2.0 \% \beta$-glucans in the diet, which indicated that high concentrations of this immunostimulant inhibited the expression of MUC2 (a quadratic response), which is in accordance with reports in C. carpio, where the increase in 
the mucus layer, rich in oligosaccharide-modified glycoproteins was observed with the administration of this immunostimulant [49]. Likewise, studies in mammals, evaluating galactooligosaccharides and fructooligosaccharides, reported a positive effect on the mucin content in the intestinal mucosa [50,51]. In this way, it is known that mucins have the ability to recognize foreign particles and bodies to give way to defensive responses, such as increased mucus lining the lumen of the intestine, which, in mice, leads to greater bacterial adhesion to the gut surface epithelium and, consequently, alterations in intestinal permeability [52,53].

As mentioned above, the intestine of fish principally performs hydrolysis of macromolecules by the action of digestive enzymes and the absorption of nutrients. In addition, the intestine functions as an immunological barrier through humoral immune factors [54]. In this way, the intestinal epithelium is characterized by a high permeability to paracellular ions, which is determined by properties of tight junctions [55]. Thus, paracellular permeability is controlled by membrane proteins, such as claudins, occludins, and tricellulines that support the exchange of chloride ions and maintain integrity of membrane proteins, among other factors [56]. This is consistent with results of the present study, where an overexpression of the OCC gene with $0.5 \% \beta$-glucans was observed. However, the expression decreased as the percentage of $\beta$-glucans in the feed increased, which suggests a negative consequence on the permeability of the cell membrane under high doses of beta glucans. These results were also reported in the herbivorous carp (Ctenopharyngodon idella, Valenciennes 1844) [57] and Scophthalmus maximus [58]. Therefore, expression of OCC in the intestine can be modified via feed formulations to improve the function of the cellular barrier against possible pathogens. In studies conducted on goldfish (Carassius auratus, Linnaeus 1758) [59], it has been reported that a low expression of OCC can affect the permeability of transmembrane junctions, causing a decrease in the intestinal epithelium that potentially lowers the resistance to pathogens by the redistribution of tight junction proteins, thereby altering the correct functioning of the intestinal barrier. However, the concentrations used in this study did not show an apparent negative effect on the health of the fish.

\section{Materials and Methods}

The present study was carried out in the facilities of the Tropical Aquaculture Laboratory in the Academic Division of Biological Sciences of the Universidad Juárez Autónoma de Tabasco (DACBIOL-UJAT). A total of 450 juveniles of $A$. tropicus (average total length $4.63 \pm 0.07 \mathrm{~mm}$ and weight $0.49 \pm 0.04 \mathrm{~g})$ were obtained from the induced spawning of one female $(3.5 \mathrm{~kg})$ and three males $(1.5 \mathrm{~kg})$ by means of an intramuscular injection of luteinizing hormone-releasing hormone analogue (Ovaprim, Syndel, Ferndale, WA, USA, $35 \mu \mathrm{g}$ ) $\mathrm{kg}_{\mathrm{g}}$ of fish ${ }^{-1}$ in the pelvic fin area. After egg hatching (day 3 post-fertilization), the eleutheroembryos were placed in circular plastic tanks of $70 \mathrm{~L}$ and a feeding scheme was followed according to previous reports [60], which started after the absorption of the yolk sack (two days after hatching [DAH] to $17 \mathrm{DAH}$ ), where Artemia nauplii were provided (2-5 nauplii $\mathrm{mL}^{-1}$ ) and from 18 to $20 \mathrm{DAH}$ co-feeding was performed with trout feed (TD, Silver Cup, $45 \%$ protein and $16 \%$ lipids) and frozen Artemia nauplii and finally from $21 \mathrm{DAH}$ were provided with formulated feed using the appropriate granulometry in relation to the size of the mouth of the larvae.

The study was conducted in accordance with the Declaration of Helsinki, and the protocol was approved by Secretaría de Agricultura, Ganadería, Desarrollo Rural, Pesca y Alimentación (NOM-062-ZOO-1999) on 18 June 2001.

\subsection{Experimental Design and Diets}

Nutritional supplementation of $\beta-1,3 / 1,6$-glucan (Macrogard, derived from yeast $S$. cerevisiae) in the following levels was evaluated and designed as: D1, $0 \%$; D2, $0.5 \%$; D3, $1.0 \%$; D4, $1.5 \%$; and D5, $2.0 \%$. The treatments were carried out in triplicate with 30 fish per experimental unit distributed in 15 circular plastic tanks of $70 \mathrm{~L}$ coupled to a recirculation system that consisted of a $1500 \mathrm{~L}$ reservoir that functions as a solidifier and a biological filter. The fish were fed five times a day $(7: 00,10: 00,12: 00$, 14:00, and 16:00 h) and partial water replacement $(10 \%)$ was made by siphoning daily. 
The diets were designed as described by Frías-Quintana [4] with the support of package MIXIT-WIN v5.0 (Agricultural Software Consultants, Inc. San Diego, CA, USA) for diet formulation (Table 3). The ingredients were sieved ( $<150$ microns) and mixed for $30 \mathrm{~min}$ in a rotating blender (CRT Global ${ }^{\circledR}$ Mix-B30GA, Nuevo León, Monterrey, Mexico), then added to the mixture of $35 \%-40 \%$ water and then pelletized ( $5 \mathrm{~mm}$ diameter) in a meat grinder (TORREY ${ }^{\circledR}$ Model M-22R1, León, Guanajuato, Mexico). The pellets were cut manually and dried in an oven (CORIAT ${ }^{\circledR}$ Model HC-35-D, Ciudad de Mexico, Mexico) at $37^{\circ} \mathrm{C}$ for $12 \mathrm{~h}$. Subsequently, they were milled and sieved to homogenize the particle size of the diets. All feeds were kept frozen at $-20{ }^{\circ} \mathrm{C}$ until use.

Table 3. Chemical composition of the formulated diet for juveniles of A. tropicus.

\begin{tabular}{|c|c|}
\hline Ingredients (g 100 g Dry Matter) & \\
\hline Feed grade Poultry by-products meal ${ }^{\mathrm{a}}$ & 42.00 \\
\hline Pork meal a & 11.60 \\
\hline Soybean meal $b$ & 4.60 \\
\hline Corn starch ${ }^{\mathrm{c}}$ & 15.40 \\
\hline Sardine oil ${ }^{\mathrm{a}}$ & 3.00 \\
\hline Fish protein hydrolizate ${ }^{a}$ & 10.00 \\
\hline Soy lecithin $\mathrm{d}$ & 3.60 \\
\hline Shrimp meal ${ }^{\mathrm{a}}$ & 3.00 \\
\hline Bovine blood meal a & 0.00 \\
\hline Grenetin $^{\mathrm{e}}$ & 2.00 \\
\hline Vitaminic premix ${ }^{f}$ & 1.00 \\
\hline Mineral premix $\mathrm{f}$ & 0.50 \\
\hline Vitamin C $\mathrm{g}$ & 0.08 \\
\hline Sorghum meal $8 \%-10 \%$ b & 3.09 \\
\hline \multicolumn{2}{|c|}{ Chemical composition ( $\%$ dry matter, except moisture. Mean \pm SD) } \\
\hline Energy $\left(\mathrm{KJ} \mathrm{g}^{-1}\right)$ & $21.549 \pm 0.04$ \\
\hline Crude protein $(\%)$ & $40.6 \pm 0.20$ \\
\hline Ether extract $(\%)$ & $16.1 \pm 0.00$ \\
\hline Fiber $(\%)$ & $1.1 \pm 0.10$ \\
\hline Ash (\%) & $10.8 \pm 0.00$ \\
\hline NFE $(\%) *$ & 31.50 \\
\hline Moisture (\%) & $4.0 \pm 0.10$ \\
\hline
\end{tabular}

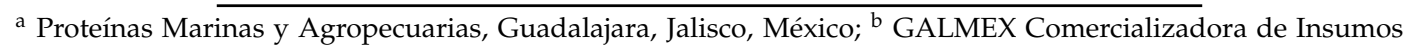
Agrícolas, Villahermosa, Tabasco, México; ${ }^{\mathrm{c}}$ MSA Industrializadora de Maíz, Guadalajara, Jalisco, México; ${ }^{\mathrm{d}}$ Pronat Ultra, Mérida, Yucatán, México; ${ }^{\text {e }} \mathrm{D}^{\prime}$ gari Productos alimenticios y dietéticos Relámpago, Tlalpan, Edomex, México; ${ }^{\mathrm{f}}$ Consorcio Súper Sociedad Anónima de Capital Variable. (for trout by courtesy), Guadalajara, Jalisco, México; g DSM (Heerlen, Netherlands, active agent 35\%). ${ }^{*}$ NFE $=$ Nitrogen free extract, calculated as $100-(\%$ Protein + $\%$ Ether extract $+\%$ Ash $+\%$ Fiber).

\subsection{Sampling and Preparation of Multienzymatic Extracts}

At the end of the experiment, the anterior intestine of six juveniles was removed (two fish per tank) in order to perform digestive enzyme activity tests; tissue samples were homogenized in a volume 1:10 with Tris- $\mathrm{HCl} 50 \mathrm{mmol} \mathrm{L}^{-1}$ buffer solution, $\mathrm{pH}$ 7.5. Subsequently, samples were centrifuged $(16,000 \times g$ for $15 \mathrm{~min}$ at $4{ }^{\circ} \mathrm{C}$ ), the supernatant was recovered, distributed in aliquots of $500 \mu \mathrm{L}$ and frozen at $-80{ }^{\circ} \mathrm{C}$ until use. The concentration of soluble protein was evaluated by means of the Bradford method [61] using as standard a bovine serum albumin curve.

Total alkaline protease activity was measured using $1 \%$ casein as a substrate in $100 \mathrm{mmol} \mathrm{L}^{-1}$ Tris- $\mathrm{HCl}$ buffer, $10 \mathrm{mmol} \mathrm{L}^{-1} \mathrm{CaCl}_{2}(\mathrm{pH}=9.0)$; the reaction was stopped with trichloroacetic acid (TCA, $10 \%$ ). The unit of enzymatic activity was defined as $1 \mu \mathrm{g}$ of tyrosine released per minute, based on the molar extinction coefficient (MEC) of $0.005 \mathrm{~mL} \mathrm{\mu g}^{-1} \mathrm{~cm}^{-1}$ [62]. The chymotrypsin activity was determined using as substrate BTEE ( $N$-benzoyl-L-tyrosine ethyl ester) $5 \mathrm{mmol} \mathrm{L}^{-1}$ in buffer Tris- $\mathrm{HCl} 44.4 \mathrm{mmol} \mathrm{L}^{-1}+\mathrm{CaCl}_{2} 55.5 \mathrm{mmol} \mathrm{L}^{-1}(\mathrm{pH}=7.8)$. One unit of enzymatic activity was defined 
as 1 mole of BTEE hydrolyzed per minute with an MEC of $964 \mathrm{~cm}^{-1} \mathrm{M}^{-1}$ [63]. The trypsin-like activity was determined using BAPNA ( $N \alpha$-Benzoyl-DL-Arginine- $P$-nitroanilide) as substrate, where a unit of enzymatic activity was defined as $1 \mu \mathrm{mol}$ of $\mathrm{P}$-nitroanilide released per minute with an MEC of $8800 \mathrm{~cm}^{-1} \mathrm{M}^{-1}$ [64]. The leucine aminopeptidase activity was determined by using $1 \mathrm{mmol} \mathrm{L}^{-1}$ L-leucine P-nitroanilide $\left(0.01 \mathrm{mmol} \mathrm{L}^{-1}\right)$ in Dimethyl sulfoxide (DMSO) as a substrate in $50 \mathrm{mmol} \mathrm{L}^{-1}$ sodium phosphate buffer at $\mathrm{pH}$ 7.2. A unit of enzymatic activity was defined as $1 \mu \mathrm{mol}$ of $\mathrm{P}$-nitroanilide released per minute with a MEC of $8800 \mathrm{~cm}^{-1} \mathrm{M}^{-1}$ [65]. The $\alpha$-amylase activity was determined using starch as substrate in citrate-phosphate buffer $100 \mathrm{mmol} \mathrm{L}^{-1}, 50 \mathrm{mmol} \mathrm{L}^{-1} \mathrm{NaCl}$. A unit was defined as the amount of enzyme that releases $1 \mu \mathrm{g}$ of maltose per minute [66]. The lipase activity was determined using as substrate $\beta$-naphthylcaprylate $\left(200 \mathrm{mmol} \mathrm{L}^{-1}\right)$ dissolved in a $50 \mathrm{mmol} \mathrm{L}^{-1}$ Tris- $\mathrm{HCl}$ buffer solution ( $\mathrm{pH}=7.2$ [67]. The lipolytic activity is defined as $1 \mu \mathrm{g}$ of naphthol released per minute with a MEC of $0.02 \mathrm{~cm}^{-1} \mathrm{M}^{-1}$.

\subsection{Growth, Survival and Food Quality Indexes}

For the evaluation of $\beta$-glucan supplementation among treatments, at the end of the experiment growth, mean weight $(\mathrm{g})$ and total length $(\mathrm{mm})$, survival (\%), SGR, FCR, and K were calculated for each replicate.

\subsection{Gene Expression}

For the assessment of the impact of $\beta$-glucan on the expression of selected genes involved in gut immunity and condition, the anterior intestine of five juveniles of $A$. tropicus was obtained from experimental tanks from each treatment $(0 \%, 0.5 \%, 1.0 \%, 1.5 \%$, and $2.0 \%$ of $\beta-1,3 / 1,6$-glucan). The samples were collected after a $24 \mathrm{~h}$ fasting period and preserved in RNAlater (volume 1:10) then stored at $-80^{\circ} \mathrm{C}$ until use. The total RNA was extracted using the Trizol reagent (Invitrogen) according to the manufacturer's instructions. The concentration and purity of the RNA was determined by spectrophotometry (NanoDrop2000, Thermo Fisher Scientific, Madrid, Spain) by measuring the absorbance at $\lambda=260$ and $280 \mathrm{~nm}$. RNA quality was verified by visualization of the $28 \mathrm{~S}$ and $18 \mathrm{~S}$ ribosomal RNA bands by $2 \%$ agarose gel electrophoresis. For the preparation of cDNA, the total RNA was treated with DNase 1, (AMPD1-1KT, Sigma-Aldrich, Broendby, Denmark), according to the manufacturer's instructions to eliminate possible contaminating genomic DNA. In a $20 \mu \mathrm{L}$ volume, $2 \mu \mathrm{g}$ of total RNA was reverse transcribed in a reaction containing SuperScript II $^{\mathrm{TM}}$ reverse transcriptase (Invitrogen), oligo (dT) $\left(0.5 \mu \mathrm{g} \mu \mathrm{L}^{-1}\right)$ and random hexamer primers (50 $\mathrm{ng} \mu \mathrm{L}^{-1}$ ). The reverse transcription reactions were prepared in $0.2 \mathrm{~mL}$ tubes following the SuperScript II First Strand cDNA Synthesis kit protocol (Invitrogen), then placed in a thermal cycler (Mastercycle ${ }^{\circledR}$ nexus GSX1, Eppendorf AG, Hamburg, Germany) and run for $5 \mathrm{~min}$ at $65{ }^{\circ} \mathrm{C}, 10 \mathrm{~min}$ at $25{ }^{\circ} \mathrm{C}$ (primer annealing), $50 \mathrm{~min}$ at $42^{\circ} \mathrm{C}$ (cDNA strand extension), $15 \mathrm{~min}$ at $70{ }^{\circ} \mathrm{C}$ (Reverse Transcrptase inactivation), and finally $20 \mathrm{~min}$ at $37^{\circ} \mathrm{C}$ (RNase $\mathrm{H}$ treatment). Negative controls (without RT enzyme) were included to confirm the absence of genomic DNA contamination. The samples were diluted 1:10 in water of molecular biological grade for analysis. To confirm the quality of all cDNA samples, duplicates of each sample were amplified using the endogenous control gene Elongation factor 1 (EF1) to establish that all samples had similar $C_{\mathrm{t}}$ values. The cDNA was stored at $-20{ }^{\circ} \mathrm{C}$ until further analysis.

The target gene sequences of A. tropicus were obtained from a previous study [68] in which pertinent genes related to gut health had been identified. The specific genes tested were the cytokines IL-10 chosen for their role in specific immune cell stimulation and TGF chosen as a proinflammatory gene involved in triggering cellular differentiation. Nucleotide oligomerization domain 2 (NOD2) was chosen as a first responder in the innate immune response for pathogen antigen recognition, while LYS is a functional effector of cell lysis for the innate immune response. Occludin (OCC) was chosen as a marker of intercellular junctions that affect gut epithelial permeability and MUC2 as a marker of mucus production and mucosal layer development. The design of specific primers for the amplification from 
cDNA for gene expression analysis was done manually using BioEdit (Ibis Therapeutics, Carlsbad, CA, USA) [69].

\subsection{Real Time Chain Polymerase Reaction (RT-qPCR)}

The qPCR relative expression analyses were carried out in triplicate using a CFX96 ${ }^{\circledR}$ Real-Time System (BioRad, Hercules, CA, USA). For each sample a master mix was prepared containing: $9.25 \mu \mathrm{L}$ SYBR Green Supermix (Applied Biosystems, Foster City, CA, USA), $0.625 \mu \mathrm{mol} \mathrm{L}^{-1}$ of each primer and $2 \mu \mathrm{L}$ of cDNA in a final volume of $25 \mu \mathrm{L}$. The q-PCR cycle was performed as follows: $10 \mathrm{~min}$ at $95^{\circ} \mathrm{C}, 45$ cycles of $95^{\circ} \mathrm{C}$ for $25 \mathrm{~s}$, followed by a recognition stage of $65^{\circ} \mathrm{C}$ for $20 \mathrm{~s}$ (the annealing temperatures were adjusted to each pair of primers), followed by $72{ }^{\circ} \mathrm{C}$ for $15 \mathrm{~s}$, with a final melting curve stage of increments of $0.5^{\circ} \mathrm{C}$ to $75^{\circ} \mathrm{C}$ to $95^{\circ} \mathrm{C}$. The amplification efficiency (E\%) for each pair of primers was evaluated to confirm the utility of each assay using five sets of ten-fold dilutions of tissue cDNA. The $\mathrm{E} \%$ calculation followed the equation: $\mathrm{E} \%=\left[10^{(-1 / \text { slope })}\right]-1$, where the "slope" is calculated from the regression line of the standard curve. EF1 and $\beta$-actin $(B A C)$ were used for the endogenous control reference genes.

\subsection{Statistical Analysis}

For the evaluation of fish growth and for gene expression analysis, a nonparametric test of Kruskal-Wallis and a posteriori Nemenyi tests were used. Survival data, food quality indexes, and enzymatic activity complied normality (K-S) and homoscedasticity (Levene) postulates, therefore were analyzed by one-way Analysis of Variance (ANOVA). For all tests, a significance of 0.05 was used, using the statistical program Statgraphics Centurion XVI ${ }^{\circledR}$ (Statgraphics Technologies, Inc., The Plains, VA, USA).

\section{Conclusions}

In our study, according to the data obtained from A. tropicus juveniles, the treatments tested that included $\beta$-glucans in the diet seem to improve growth, survival, digestive enzyme activities, some immune system responses, and the integrity of the intestinal barrier. In this sense, the effect of $\beta$-glucans in different fish species depends on the dosage, duration of feeding with the additive, and the stage of life of the organism. For this reason, we should consider to evaluate a lower dose of $\beta$-glucan $(<0.5 \%)$, and to determine changes in cellular morphology through histological techniques and perform challenges with pathogenic bacteria with the objective of increasing knowledge about the effect of $\beta$-glucans prebiotics on ancestral teleosts.

Author Contributions: C.A.A.-G., F.V.-V., and E.G. were the scientific leaders and the project supervisors. E.P.-M., D.T.-R., and L.T.G.-V. designed the experiments presented in this paper; K.B.A. designed the gene expression assays, directed the molecular analyses, and revised the English language; K.N.N.-R. performed the experiments and conducted the biochemical and molecular analyses. Finally, R.M.-G. and S.C.-C. help to revise and edit the manuscript.

Funding: This research received external funding from the National Council of Science and Technology of Mexico "Strengthening of the Master's Degree in Environmental Sciences for its Permanence in the National Register of Quality Graduates of CONACYT Key: TAB-2014-C29-245836". Gene expression analyses were supported and funded by IRTA-SCR (Spain).

Acknowledgments: The author thanks the National Council of Science and Technology of Mexico for the thesis scholarship for postgraduate studies and the mixed scholarship granted to carry out the research stay at the IRTA-SCR (Spain).

Conflicts of Interest: The authors declare no conflicts of interest. 


\section{References}

1. Marquez-Couturier, G.; Álvarez-Gonzalez, C.A.; Contreras, W.M.; Hernández-Vidal, U.; Hernández-Franyutti, A.A.; Mendoza-Alfaro, R.E.; Aguilera-Gonzalez, C.; Garcia-Galano, T.; Civera-Cerecedo, R.; Goytortua-Bores, E. Avances en la alimentación y nutrición del pejelagarto Atractosteus tropicus. In Memorias de VIII Simposium Internacional de Nutrición Acuicola, Proceedings of the Avances en Nutrición Acuícola VIII. VIII Simposium Internacional de Nutrición Acuícola, Universidad Autónoma de Nuevo León, Monterrey, Nuevo León, México, 15-17 November 2006; Cruz Suárez, L.E., Ricque Marie, D., Nieto López, M.G., Tapia Salazar, M., Villarreal Cavazos, D., Puello Cruz, A.C., García Ortega, A., Eds.; UANL: Monterrey, Nuevo León, México, 2006; pp. 446-532.

2. López-Ramírez, G.; Cuenca-Soria, C.A.; Álvarez-González, C.A.; Tovar-Ramírez, D.; Ortiz-Galindo, J.L.; Perales-García, N.; Márquez-Couturier, G.; Arias-Rodríguez, L.; Indy, J.R.; Contreras-Sánchez, W.M.; et al. Development of digestive enzymes in larvae of Mayan cichlid Cichlasoma urophthalmus. Fish Physiol. Biochem. 2010, 37, 197-208. [CrossRef] [PubMed]

3. Alvarez-González, C.A.; Marquez-Couturier, G.; Contreras-Sánchez, W.M.; Rodríguez-Valencia, W. Strategy for the sustainable use of fisheries resources in Boca Chilapa, biosphere reserve Centla Swamp, Tabasco: Establishment of a production plant native fish: Alligator gar, Snook and Mayan cichlid. In Towards a Culture of Conservation of Biological Diversity; Halffter, G., Guevara, S., Melic, A., Eds.; Monographs millennium: Zaragoza, Spain, 2007; Volume 6, pp. 197-205.

4. Frías-Quintana, C.A.; Márquez-Couturier, G.; Álvarez-González, C.A.; Tovar-Ramírez, D.; Nolasco-Soria, H.; Galaviz-Espinosa, M.A.; Martínez-García, R.; Camarillo-Coop, S.; Martínez-Yañes, R.; Gisbert, E. Development of digestive tract and enzyme activities during the early ontogeny of the tropical gar Atractosteus tropicus. Fish Physiol. Biochem. 2015, 41, 1075-1091. [CrossRef] [PubMed]

5. Frías-Quintana, C.A.; Dominguez-Lorenzo, J.; Alvarez-Gonzalez, C.A.; Tovar-Ramirez, D.; Martinez-Garcia, R. Uing cornstarch in microparticulate diets for larvicultured tropical gar (Atractosteus tropppicus). Fish Physiol. Biochem. 2016, 42, 517-528. [CrossRef] [PubMed]

6. Flores-Aguilar, R.A. Efecto inmunoestimulador y tecnología de producción de oligosacáridos (beta $(1,3-1,6)$ glucanos) extraídos de algas pardas cultivadas y su evaluación en el cultivo de peces y moluscos. Comisión Nacional de Investigación en ciencia. In Proceedings of the XV Concurre de Proyectos De I+D FONDEF 2007, Santiago, Chile, 31 October 2007.

7. Rodríguez, F.; Esteban, M.; Meseguer, J.; Bravo, M.; Gómez, G.; Rojas-Luna, T.; Jiménez, G.; Balcázar, J. Estrategias de control de enfermedades en Acuicultura II Congreso Iberoamericano Virtual de Acuicultura. CIVA 2003; pp. 624-654. Available online: http:/ / www.civa2003.org (accessed on 12 March 2017).

8. Dalmo, R.A.; Bogwald, J. $\beta$-glucans as conductors of immune symphonies. Review. Fish Shellfish Immunol. 2008, 25, 384-396. [CrossRef] [PubMed]

9. Lin, S.; Pan, Y.; Luo, L.; Luo, L. Effects of dietary $\beta$-1,3-glucan, chitosan or raffinose on the growth, innate immunity and resistance of koi (Cyprinus carpio koi). Fish Shellfish Immunol. 2011, 31, 788-794. [CrossRef] [PubMed]

10. Guzmán-Villanueva, L.T.; Ascencio-Valle, F.; Macías-Rodríguez, M.E.; Tovar-Ramírez, D. Effects of dietary $\beta-1,3 / 1,6$-glucan on the antioxidant and digestive enzyme activities of Pacific red snapper (Lutjanus peru) after exposure to lipopolysaccharides. Fish Physiol. Biochem. 2013, 40, 827-837. [CrossRef] [PubMed]

11. Falco, A.; Frost, P.; Miest, J.; Pionnier, N.; Irnazarow, I.; Hoole, D. Reduced inflammatory response to Aeromonas salmonicida infection un common carp (Cyprinus carpio L.) fed with $\beta$-glucan supplements. Fish Shellfish Immunol. 2012, 32, 1051-1057. [CrossRef] [PubMed]

12. Cook, M.T.; Hayball, P.J.; Hutchinson, W.; Nowak, B.F.; Hayball, J.D. Administration of a commercial Inmunoestimulant preparation, EcoActiva as a feed supplement enhances macrophages from pink snapper (Pagrus auratus, Sparidae (Bloch and Schneider)). Fish Shellfish Immunol. 2003, 14, 333-345. [CrossRef] [PubMed]

13. Misra, C.K.; Mukherjee, S.; Pattnaik, P. Effect on long term administration of dietary $\beta$-glucan on inmunity, growth and survival of Labeo rohita fingerlings. Aquaculture 2006, 255, 82-94. [CrossRef]

14. Welker, T.L.; Lim, C.; Yildrim-Aksoy, M.; Shelby, R.; Klesius, P.H. Immune response and resistance to stress and Edwardsiella ictaluri challenge in channel catfish Ictalurus punctatus, fed diets containing commercial whole-cell or yeast subcomponents. J. World Aquac. Soc. 2007, 38, 24-35. [CrossRef] 
15. Sealey, W.M.; Barrows, F.T.; Hang, A.; Johansen, K.A.; Overturf, K.; LaPatra, S.E.; Hardy, R.W. Evaluation of the ability of barley genotypes containing different amount of $\beta$-glucan to alter growth and disease resistance of rainbow trout (Oncorhynchus mykiss). Anim. Feed Sci. Technol. 2008, 141, 115-128. [CrossRef]

16. Selvaraj, V.; Sampath, K.; Sekar, V. Administration of yeast glucan enhances survival and some non-specific and specific immune parameters in carp (Cyprinus carpio) infected with Aeromonas hydrophyla. Fish Shellfish Immunol. 2005, 19, 2293-2306. [CrossRef] [PubMed]

17. Lovoll, M.; Fischer, U.; Mathisen, G.S.; Bogwald, J.; Ototake, M.; Dalmo, R.A. The C3 subtype are differentially regulated after immunostimulation in rainbow trout, but head kidney macrophages do not contribute to $\mathrm{C} 3$ transcription. Vet. Immunol. Immunopathol. 2007, 117, 284-295. [CrossRef] [PubMed]

18. Paulsen, S.M.; Engstad, R.E.; Robertsen, B. Enhanced lysozyme production in Atlantic salmon (Salmo salar L.) macrophages treated with yeast $\beta$-glucan and bacterial lipopolysaccharide. Fish Shellfish Immunol. 2001, 11, 23-37. [CrossRef] [PubMed]

19. Jorgensen, J.B.; Sharp, G.J.E.; Secombes, C.J.; Robertsen, B. Effects of a yeast-cell-wall glucan on the bactericidal activity of rainbow trout macropages. Fish Shellfish Immunol. 1993, 3, 267-277. [CrossRef]

20. Kunttu, H.M.; Valtonen, E.T.; Suomalainen, L.R.; Vielma, J.; Jokinen, I.E. The efficacy of two immunostimulants against Flavobacterium columnare infection in juvenile rainbow trout (Oncorhynchus mykiss). Fish Shellfish Immunol. 2009, 26, 850-857. [CrossRef] [PubMed]

21. Del Rio-Zaragoza, O.B.; Fajer-Avila, E.J.; Almazan-Rueda, P. Influence of $\beta$-glucan on innate immunity and resistance of Lutjanus guttatus to an experimental infection of dactylogyrid monogeneans. Parasite Immunol. 2011, 33, 483-494. [CrossRef] [PubMed]

22. Falco, A.; Miest, J.J.; Pionnier, N.; Pietretti, D.; Forlenza, M.; Wiegertjes, G.F.; Hoole, D. $\beta$-Glucan-supplemented diets increase poly (I: C)-induced gene expression of Mx, possibly via Tlr3-mediated recognition mechanism in common carp (Cyprinus carpio). Fish Shellfish Immunol. 2014, 36, 494-502. [CrossRef] [PubMed]

23. Pionnier, N.; Falco, A.; Miest, J.; Shrive, A.K.; Hoole, D. Feeding common carp Cyprinus carpio with $\beta$-glucan supplemented diet stimulates $C$-reactive protein and complement immune acute phase responses following PAMPs injection. Fish Shellfish Immunol. 2014, 39, 285-295. [CrossRef] [PubMed]

24. Sahoo, P.K.; Mukherjee, S.C. Effect of dietary $\beta-1,3$ glucan on immune responses and disease resistance of healthy and aflatoxin B1-induced immunocompromised rohu (Labeo rohita Hamilton). Fish Shellfish Immunol. 2001, 11, 683-695. [CrossRef] [PubMed]

25. Rodriguez, A.; Cuesta, A.; Ortuno, J.; Esteban, M.A.; Meseguer, J. Immunostimulant properties of a cell wall-modified whole Saccharomyces cerevisiae strain administered by diet to seabream (Sparus aurata L.). Vet. Immunol. Immunopathol. 2003, 96, 183-192. [CrossRef] [PubMed]

26. Bagni, M.; Archetti, L.; Amadori, M.; Marino, G. Effect of long-term oral administration of an immunostimulant diet on innate immunity in sea bass (Dicentrarchus labrax). Zoonoses Public Health 2000, 47, 745-751. [CrossRef]

27. Bagni, M.; Romano, N.; Finoia, M.G.; Abelli, L.; Scapigliati, G.; Tiscar, P.G.; Sarti, M.; Marino, G. Short-and long-term effects of a dietary yeast $\beta$-glucan (Macrogard) and alginic acid (Ergosan) preparation on immune response in sea bass (Dicentrarchus labrax). Fish Shellfish Immunol. 2005, 18, 311-325. [CrossRef] [PubMed]

28. El-Boshy, M.E.; Ahmed, M.; AbdelHamid, F.M.; Gadalla, H.A. Immunomodulatory effect of dietary Saccharomyces cerevisiae, $\beta$-glucan and laminarian in mercuric chloride treated Nile tilapia (Oreochromis niloticus) and experimentally infected with Aeromonas hydrophila. Fish Shellfish Immunol. 2010, 28, 802-808. [CrossRef] [PubMed]

29. Ai, Q.; Mai, K.; Zhang, L.; Tan, B.; Zhang, W.; Xu, W.; Li, H. Effects of dietary $\beta-1,3$ glucan on innate immune response of large yellow croaker, Pseudosciaena crocea. Fish Shellfish Immunol. 2007, 22, 394-402. [CrossRef] [PubMed]

30. Kirchhoff, N.T.; D'Antignana, T.; Leef, M.J.; Hayward, C.J.; Wilkinson, R.J.; Nowak, B.F. Effects of immunostimulants on ranched southern bluefin tuna Thunnus maccoyii: Immune response, health and performance. J. Fish Biol. 2011, 79, 331-355. [CrossRef] [PubMed]

31. Vallejos-Vidal, E.; Reyes-López, F.; Teles, M.; MacKenzie, S. The response of fish to immunostimulant diets. Fish Shellfish Immunol. 2016, 56, 34-69. [CrossRef] [PubMed]

32. Wang, W.; Sun, J.; Liu, C.; Xue, Z. Application of immunostimulants in aquaculture: Current knowledge and future perspectives. Aquac. Res. 2017, 48, 1-23. [CrossRef] 
33. Lopez, N.; Cuzon, G.; Gaxiola, G.; Taboada, G.; Valenzuela, M.; Pascual, C.; Sanchez, A.; Rosas, C. Physiological, nutritional, and immunological role of dietary $\beta-1,3$ glucan and ascorbic acid 2-monophosphate in Litopenaeus vannamei juveniles. Aquaculture 2003, 224, 223-243. [CrossRef]

34. Sakai, M. Current research status of fish immunostimulants. Aquaculture 1999, 172, 63-92. [CrossRef]

35. Fuchs, V.I.; Schmidt, J.; Slater, M.J.; Zentek, J.; Buck, B.H.; Steinhagen, D. The effect of supplementation with polysaccharides, nucleotides, acidifiers and Bacillus strains in fish meal and soy bean based diets on growth performance in juvenile turbot (Scophthalmus maximus). Aquaculture 2015, 437, 243-251. [CrossRef]

36. Ji, L.; Sun, G.; Li, J.; Wang, Y.; Du, Y.; Li, X.; Liu, Y. Effect of dietary $\beta$-glucan on growth, survival and regulation of immune processes in rainbow trout (Oncorhynchus mykiss) infected by Aeromonas salmonicida. Fish Shellfish Immunol. 2017, 64, 56-67. [CrossRef] [PubMed]

37. Skjermo, J.; Størseth, T.R.; Hansen, K.; Handå, A.; Oie, G. Evaluation of $\beta-(1 \rightarrow 3,1 \rightarrow 6)$-glucans and High-M alginate used as immunostimulatory dietary supplement during first feeding and weaning of Atlantic cod (Gadus morhua L.). Aquaculture 2006, 261, 1088-1101. [CrossRef]

38. Meena, D.K.; Das, P.; Kumar, S.; Mandal, S.C.; Prusty, A.K.; Singh, S.K.; Akhtar, M.S.; Behera, B.K.; Kumar, K.; Pal, A.K.; et al. Beta-glucan: An ideal immunostimulant in aquaculture (a review). Fish Physiol. Biochem. 2013, 39, 431-457. [CrossRef] [PubMed]

39. Aramli, M.S.; Kamangar, B.; Nazari, R.M. Effects of dietary $\beta$-glucan on the growth and innate immune response of juvenile Persian sturgeon, Acipenser persicus. Fish Shellfish Immunol. 2015, 47, 606-610. [CrossRef] [PubMed]

40. Whittington, R.; Lim, C.; Klesius, P.H. Effect of dietary $\beta$-glucan levels on the growth response and efficacy of Streptococcus iniae vaccine in Nile tilapia, Oreochromis niloticus. Aquaculture 2005, 248, 217-225. [CrossRef]

41. Cara, C.; Moya, M.; Ballesteros, I.; Negro, M.J.; Gonzalez, A.; Ruiz, E. Influence of solid loading on enzymatic hydrolysis of steam exploded or liquid hot water pretreated olive tree biomass. Proc. Biochem. 2007, 42, 1003-1009. [CrossRef]

42. Pedrotti, F.S.; Davies, S.; Merrifield, D.L.; Marques, M.R.; Fraga, A.P.M.; Mouriño, J.L.; Fracalossi, D.F. The autochthonous microbiota of the freshwater omnivores jundia (Rhamdia quelen) and tilapia (Oreochromis niloticus) and the effect of dietary carbohydrates. Aquac. Res. 2013, 46, 472-481. [CrossRef]

43. Williams, D.M.; Grubbs, B.G.; Park-Snyder, S.; Rank, R.G.; Bonewald, L.F. Activation of latent transforming growth factor beta during Chlamydia trachomatis-induced murine pneumonia. Res. Microbiol. 1996, 147, 251-262. [CrossRef]

44. Netea, M.G.; Sutmuller, R.; Hermann, C.; Van der Graaf, C.A.; Van der Meer, J.W.; van Krieken, J.H.; Hartung, T.; Adema, G.; Kullberg, B.J. Toll-Like Receptor 2 Suppresses Immunity against Candida albicans through Induction of $I L-10$ and Regulatory T Cells. J. Immunol. 2004, 172, 3712-3718. [CrossRef] [PubMed]

45. Zhang, Z.; Swain, T.; Bøgwald, J.; Dalmo, R.A.; Kumari, J. Bath immunostimulation of rainbow trout (Oncorhynchus mykiss) fry induces enhancement of inflammatory cytokine transcripts, while repeated bath induce no changes. Fish Shellfish Immunol. 2009, 26, 677-684. [CrossRef] [PubMed]

46. Douxfils, J.; Fierro-Castro, C.; Mandiki, S.N.M.; Wakson, E.; Lluis, T.; Kestemont, P. Dietary $\beta$-glucans differentially modulate immune and stress-related gene expression in lymphoid organs from healthy and Aeromonas hydrophila-infected rainbow trout (Oncorhynchus mykiss). Fish Shellfish Immunol. 2017, 63, 285-296. [CrossRef] [PubMed]

47. Dalmo, R.A.; Ingebrigtsen, K.; Bøgwald, J. Non-specific defenses mechanisms in fish, with particular reference to the reticuloendothelial system (RES). J. Fish Dis. 1997, 20, 241-273. [CrossRef]

48. Gomez, D.; Sunyer, J.O.; Salinas, I. The mucosal immune system of fish: The evolution of tolerating commensals while fighting pathogens. Fish Shellfish Immunol. 2013, 35, 1729-1739. [CrossRef] [PubMed]

49. Neuhaus, H.; Van der Marel, M.; Caspari, N.; Meyer, W.; Enss, M.L.; Steinhagen, D. Biochemical and histochemical study on the intestinal mucosa of the common carp Cyprinus carpio L., with special consideration of mucin glycoproteins. J. Fish Biol. 2007, 70, 1523-1534. [CrossRef]

50. Tsukahara, T.; Iwasaki, Y.; Nakayama, K.; Ushida, K. Stimulation of butyrate production in the large intestine of weaning piglets by dietary fructooligosaccharides and its influence on the histological variables of the large intestinal mucosa. J. Nutr. Sci. Vitaminol. 2003, 49, 414-421. [CrossRef] [PubMed]

51. Leforestier, G.; Blais, A.; Blachier, F.; Marsset-Baglieri, A.; Davila-Gay, A.M.; Perrin, E.; Tomé, D. Effects of galacto-oligosaccharide ingestion on the mucosa-associated mucins and sucrase activity in the small intestine of mice. Eur. J. Nutr. 2009, 48, 457-464. [CrossRef] [PubMed] 
52. Sunyer, J.O.; Tort, L. Natural hemolytic and bactericidal activities of sea bream Sparus aurata serum are affected by the alternative complement pathway. Vet. Immunol. Immunopathol. 1995, 45, 333-345. [CrossRef]

53. Kim, Y.S.; Ho, S.B. Intestinal goblet cells and mucins in health and disease: Recent insights and progress. Curr. Gastroenterol. Rep. 2010, 12, 319-330. [CrossRef] [PubMed]

54. Walker, W.A. Antigen uptake in the gut: Immunologic implications. Immunol. Today 1981, 2, 30-34. [CrossRef]

55. Loretz, C.A. Electrophysiology of ion transport in teleost intestinal cells. Fish Physiol. 1995, 14, 25-56. [CrossRef]

56. Tsukita, S.; Yamazaki, Y.; Katsuno, T.; Tamura, A.; Tsukita, S. Tight junction-based epithelial microenvironment and cell proliferation. Oncogene 2008, 27, 6930-6938. [CrossRef] [PubMed]

57. Fei-Yu, P.; Pei, W.; Lin, F.; Wei-Dan, J.; Sheng-Yao, K.; Ling, T.; Wu-Neng, T.; Yong-An, Z.; Xiao-Qiu, Z.; Yang, L. Methionine hydroxy analogue improves intestinal immunological and physical barrier function in young grass carp (Ctenopharyngodon idella). Fish Shellfish Immunol. 2017, 64, 122-136. [CrossRef]

58. Yang, P.; Hu, H.; Liu, Y.; Li, Y.; Ai, Q.; Xu, W.; Zhang, W.; Zhang, Y.; Zhang, Y.; Mai, K. Dietary stachyose altered the intestinal microbiota profile and improved the intestinal mucosal barrier function of juvenile turbot, Scophthalmus maximus L. Aquaculture 2018, 486, 98-106. [CrossRef]

59. Chasiotis, H.; Kelly, S.P. Occludin immunolocalization and protein expression in goldfish. J. Exp. Biol. 2008, 211, 1524-1534. [CrossRef] [PubMed]

60. Frías-Quintana, C.A.; Alvarez-González, C.A.; Marquez-Couturer, G. Diseño de microdietas para el larvicultivo de pejelagarto Atractosteus tropicus, Gill 1863. Universidad y Ciencia 2010, 26, 265-282.

61. Bradford, M.M. A rapid and sensitive method for the quantitation of microgram quantities of protein utilizing the principle of protein-dye binding. Anal. Biochem. 1976, 72, 248-254. [CrossRef]

62. Walter, H.E. Proteinases: Methods with hemoglobin, casein and azocoll as substrates. In Methods of Enzymatic Analysis; Bergmeyern, H.J., Ed.; Verlag Chemie: Weinheim, Germany, 1984; Volume 1, pp. 270-277.

63. Del Mar, E.G.; Largman, C.; Brodrick, J.; Geokas, M. A sensitive new substrate for chymotrypsin. Anal. Biochem. 1979, 99, 316-377. [CrossRef]

64. Erlanger, B.; Kokowsky, N.; Cohen, W. The preparation and properties of two new chromogenic substrates of trypsin. Arch. Biochem. Biophys. 1961, 95, 271-278. [CrossRef]

65. Maroux, S.; Louvard, D.; Baratti, J. The aminopeptidase from hog-intestinal brush border. Biochim. Biophys. Acta 1973, 321, 282-295. [CrossRef]

66. Robyt, J.F.; Whelan, W. Amylases Starch and its Derivates; Readlet, J.A., Ed.; Chapman and Hall: London, UK, 1968; pp. 430-476.

67. Versaw, W.K.; Cuppett, S.L.; Winters, D.D.; Williams, L.E. An Improved Colorimetric Assay for Bacterial Lipase in Nonfat Dry Milk. J. Food Sci. 1989, 54, 1557-1558. [CrossRef]

68. Martinez-Burguete, T.; Peña, E.; Llera, R.; Alvarez-González, C.A. Transcriptome analysis during early ontogeny of tropical gar Atractosteus tropicus: Detecting nutrigenomic markers. In Larvi'17-Fish and Shellfish Larviculture Symposium; Hendry, C.I., Ed.; European Aquaculture Society: Ostend, Belgium, 2017; pp. 281-284.

69. Bioedit. Available online: http:/ / www.mbio.ncsu.edu/BioEdit/bioedit.html (accessed on 25 October 2017).

(C) 2018 by the authors. Licensee MDPI, Basel, Switzerland. This article is an open access article distributed under the terms and conditions of the Creative Commons Attribution (CC BY) license (http:/ / creativecommons.org/licenses/by/4.0/). 